INOBIS: Jurnal Inovasi Bisnis dan Manajemen Indonesia

Volume 1, Nomor 1, Desember 2017

Syaifuddin Fahmi

\title{
Analisis Perkembangan Riset Pemasaran Tentang Perilaku Konsumen Dalam Melakukan Perpindahan Layanan (Consumer Switching Behavior), Menggunakan Studi Literatur
}

\author{
Syaifuddin Fahmi \\ Sekolah Tinggi Ilmu Ekonomi Kertanegara Malang \\ Syaifuddin_fahmi@stiekma.ac.id
}

\begin{abstract}
Abstrak
Perilaku perpindahan pelanggan terjadi saat pelanggan meninggalkan layanan atau produk awal yang mereka gunakan dan menggantinya dengan produk atau layanan baru. Fenomena ini menarik untuk diteliti seiring dengan ketatnya persaingan dan perkembangan teknologi yang memunculkan banyak alternatif produk dan layanan untuk dipilih oleh konsumen. Penelitian ini bertujuan untuk menganalisis perkembangan riset di bidang perilaku perpindahan layanan yang dilakukan oleh konsumen. Metode yang dipergunakan adalah literatur review, yaitu dengan menganalisis jurnal yang terbit pada tahun 2010 sampai dengan 2017 pada publisher emerald dan elsevier. Keyword yang dipergunakan untuk mencari adalah "consumer switching behavior". Hasil studi pada 13 artikel jurnal ditemukan bahwa variabel yang dipergunakan untuk menganalisis perilaku perpindahan layanan di ambil dari beberapa teori perilaku yang sudah banyak dipergunakan, seperti Theory of Reasoned Action (TRA), Theory of Planned Behavior (TPB), dan Technology Acceptance Model (TAM). Sedangkan beberapa penelitian terbaru menunjukkan bahwa teori push and pull mooring dirasakan lebih tepat dipergunakan untuk mengukur dan menganalisis perilaku perpindahan layanan "switching behavior". Yaitu dengan memasukkan faktor pendorong (push factors), faktor penarik (pull factors) dan faktor yang menjadi penghambat perpindahan (mooring factors).
\end{abstract}

Kata Kunci : TRA, TPB, TAM, Push Factor, Pull Factor, Mooring Factor

\section{Pendahuluan}

Jumlah pengguna media online secara global menunjukkan angka sekitar 1,3 miliar pada akhir tahun 2007. Proyeksi menunjukkan bahwa angka tersebut akan mencapai 1,8 miliar pada tahun 2010 dan akan semakin tinggi di tahun 2017. Akses internet dunia berkembang begitu pesat sehingga orang sekarang online hampir setiap hari untuk melakukan segala sesuatu mulai dari pengecekan pernyataan bank mereka, untuk berbelanja, untuk mencari informasi atau hanya sekedar mencari hiburan dan bermain game. Pemanfaatan teknologi informasi di Indonesia dalam mendukung aktifitas masyarakat mengalami pertumbuhan yang sangat pesat, seiring dengan pertumbuhan jumlah pengguna smartphone dan media internet yang angkanya mencapai 83,7 juta orang pada 2014 (https://www.kominfo.go.id, 2014). Tahun 2016 pengguna internet di indonesia meningkat menjadi 132,7 juta orang diperkirakan akan terus mengalami kenaikkan di tahun 2017 (Internetworldstats.com, 2016). Jumlah tersebut mendudukkan Indonesia di peringkat ke-6 terbesar di dunia dalam hal jumlah pengguna internet. Perkembangan dalam bidang teknologi informasi berdampak pada iklim bisnis yang menjadi semakin kompetetif. Sebagai konsekuensinya volume kegiatan ekonomi digital menjadi semakin masif. Interaksi individu lintas negara dalam kaitannya dengan kegiatan perdagangan dan bisnis menjadi semakin cepat. 
INOBIS: Jurnal Inovasi Bisnis dan Manajemen Indonesia

Volume 1, Nomor 1, Desember 2017

\section{Syaifuddin Fahmi}

Hadirnya teknologi informasi menyebabkan banyak perubahan pada masyarakat indonesia, Layanan kemudahan dan fasilitas yang ditawarkan media online membuat beberapa konsumen memilih untuk menggunakan media digital sebagai alternatif dalam pemenuhan kebutuhan sehari-hari, seperti berbelanja kebutuhan pokok dan pelayanan jasa (James Reardon dan D.E. McCorkle, 2017). Untuk memenuhi kebutuhan yang sangat besar tersebut saat ini banyak bermunculan bisnis baru berbasis aplikasi berbentuk start-up dan ecommerce, bahkan beberapa perusahaan start-up dan e-commerce asli indonesia ada yang telah mendapatkan pengakuan internasional melalui bantuan pendanaan yang nilainya mencapai lebih dari angka 2 trilliun rupiah seperti prestasi dari PT. Gojek Indonesia dan Tokopedia (http://www.tempo.co, 2017). Sejalan dengan perubahan perilaku konsumen sebagai dampak dari pertumbuhan teknologi informasi banyak riset yang dilakukan dengan mengambil topik tersebut, diantaranya adalah riset tentang perilaku berpindah pelanggan (switching behavior) dari yang awalnya menggunakan produk-produk yang ditawarkan secara langsung atau konvensional, menuju penggunaan layanan digital dan produk-produk online.

Perilaku perpindahan pelanggan terjadi saat pelanggan meninggalkan layanan atau produk awal yang mereka gunakan dan menggantinya dengan produk atau layanan baru, sehingga penyedia asli kehilangan keuntungan di masa depan dan menanggung biaya untuk mengakuisisi pelanggan baru (M. S. Keaveney, 1995). Penyedia jasa membutuhkan kehadiran pelanggan dan keanggotaan pelanggan, karena ini perusahaan umumnya mengandalkan skala ekonomi dan membutuhkan sejumlah besar pelanggan untuk berbagi biaya tetap (S. M. d. P. Keaveney, M. , 2001). Perpindahan pelanggan berdampak pada basis biaya pada perusahaan berbasis penyedia layanan. Keaveney dan Parthasarathy (2001) mencatat bahwa pelanggan yang loyal dapat menghasilkan banyak keuntungan, termasuk kontribusi marjinal yang relatif tinggi, biaya penjualan yang relatif rendah dan penjualan word-of-mouth positif.

Dalam hal ini perilaku berpindah ditentukan oleh faktor penarik dan pendorong yang merangsang konsumen. Studi yang berbeda dilakukan oleh Amelie Gamble, dkk (2009) yang meneliti kegagalan konsumen untuk beralih, penelitian ini menyelidiki bahan konsumen untuk sikap negatif terhadap perpindahan pasar swalayan Swedia, telekomunikasi darat, dan asuransi rumah. Berdasarkan hasil survei sikap negatif terhadap pemasok beralih terbukti meningkat dengan loyalitas, meningkat seiring dengan biaya pencarian informasi dan penurunan dengan manfaat ekonomi yang diharapkan. Sikap terhadap switching lebih negatif di pasar listrik daripada di pasar lain dan lebih negatif di pasar telekomunikasi darat daripada di pasar asuransi rumah. Perbedaan antara pasar dipertanggungjawabkan oleh perbedaan loyalitas, biaya pencarian informasi, dan manfaat ekonomi yang diharapkan, (Amelie Gamble, 2009).

Philip Gerrard, dkk (2004), mengidentifikasi jenis insiden yang menyebabkan konsumen beralih pada layanan bank, pembobotan setiap kejadian pada keputusan switching, apakah insiden tunggal atau multipel mempengaruhi keputusan perpindahan, dan sejauh mana pengalih menjelaskan masalah yang mereka hadapi sebelum keluar Temuan utama menunjukkan bahwa peralihan bank sangat dipengaruhi oleh tiga jenis insiden: kegagalan layanan, harga dan ketidaknyamanan, dengan penetapan harga menjadi lebih berpengaruh. Tujuh puluh lima persen dari switching bank disebabkan oleh lebih dari satu insiden, dan sekitar 7 persen responden mengatakan bahwa mereka telah berbicara dengan staf bank pada periode sebelum keluar, (Philip Gerrard, 2004). Implikasi dari temuan ini disajikan. Model switching yang dikembangkan oleh Keaveney (1995) merupakan langkah maju yang besar dalam memahami perilaku beralih konsumen di spektrum yang luas dari penyedia layanan. Itu studi Keaveney (1995) bertindak sebagai stimulus bagi mereka yang melakukan penelitian pada sektor industri jasa tertentu, seperti bank. Gerrard dan Cunningham (2000) menilai model delapan kejadian Keaveney (1995) saat menyelidiki perilaku switching nasabah bank. 
INOBIS: Jurnal Inovasi Bisnis dan Manajemen Indonesia

Volume 1, Nomor 1, Desember 2017

\section{Syaifuddin Fahmi}

Temuan mereka konsisten dengan Keaveney (1995) sehubungan dengan kejadian switching yang paling berpengaruh. Dalam mengembangkan kesadaran akan perilaku switching yang lebih besar, para periset telah mencoba untuk menanggapi beberapa keterbatasan studi masa lalu. Keaveney (1995), misalnya, menganggap bahwa semua konsumen memiliki bobot yang sama terhadap masing-masing insiden yang menyebabkan konsumen berpindah antar penyedia layanan. Gerrard dan Cunningham (2000) mengembangkan metode pembobotan sederhana yang diterapkan pada berbagai insiden switching yang mereka ciptakan. Namun, sampai saat ini, tidak ada yang meminta pengalih perhatian untuk memberi bobot pada berbagai insiden yang menyebabkan mereka beralih,

Perilaku berpindah pelanggan telah dipelajari di berbagai bidang seperti layanan perbankan, seperti penelitian yang dilakukan oleh (Michael D. Clemes, 2010), service provider (Yongqiang Sun \& c, 2017), perpindahan merek (Arvind Sahay and Nivedita Sharma), belanja online, hi-tech produk (Zeeshan Ahmed 2015), pemilihan maskapai penerbangan (Jishim Jung, 2017), situs jejaring sosial (Chun-Nan Lin, 2017), dll. (Sanjukta Pookulangara, 2011), meneliti perilaku berpindah konsumen dengan menggunakan Theory of Planned Behavior (TPB). Teori ini mengasumsikan bahwa sikap dan kepercayaan individu, bersama dengan norma subyektif dan faktor kontrol, akan mengarah pada niat untuk melakukan perilaku tertentu, baik untuk mengganti saluran atau tidak. Berdasarkan hasil survei online yang dilakukan di empat lokasi penelitian yang berbeda dan melibatkan 547 responden, diketahui bahwa Sikap terhadap perpindahan saluran dipengaruhi secara signifikan oleh kepercayaan hedonis dan utilitarian di toko dan katalog. Namun, dalam kasus saluran Internet, sikap terhadap perpindahan saluran hanya dipengaruhi oleh kepercayaan utilitarian.

Berkaitan dengan perilaku berpindah (beralih), studi yang paling terkenal dilakukan oleh (M. S. Keaveney, 1995) setelah meneliti lebih dari 500 konsumen. Keaveney mengidentifikasi berbagai alasan penting yang menyebabkan pelanggan beralih dari penyedia jasa asal (awal) mereka. Atas dasar ini, Keaveney mengelompokkan alasan bagi pelanggan yang berpindah ke dalam delapan kategori berikut: (i) core service failure, (ii) service encounter failure, (iii) employee responses to service failures, (iv)pricing, (v) inconvenience, (vi) attracted by a competitor, (vii) ethical issues, and (viii) involuntary switching. Dalam penelitian kualitatif ini, Keaveney juga memaparkan bahwa lebih dari setengah dari pelanggan beralih karena persepsi harga murah (dibandingkan dengan pesaing). Dalam penelitian Keaveney yang lain (bersama Parthasarathy), terungkap bahwa pelanggan tertentu akan memiliki kecenderungan lebih besar untuk beralih penyedia jasa dan tidak mempedulikan bagaimana situasi kegagalan jasa (service failures) ditangani (Keaveney dan Parthasarathy, 2001). Kau dan Loh (2006) dan Singh (1990) menegaskan bahwa perilaku yang paling mungkin terjadi setelah kegagalan produk di antaranya yaitu keluar dan beralih. Sebagai tambahan, hasil studi (S. M. d. P. Keaveney, M. , 2001) ini juga menunjukkan bahwa dalam konteks layanan online, faktor-faktor demografis seperti usia dan pendapatan, serta faktor-faktor individu seperti penghindaran risiko, mempengaruhi apakah seorang pelanggan terus menggunakan layanan online atau beralih ke operator lain

Dengan banyaknya pendekatan dan bidang kajian terhadap riset perilaku perpindahan konsumen, maka studi literatur perlu dilakukan untuk bisa melihat dan memetakkan perkembangan penelitian dari waktu-kewaktu. Sehingga kita bisa mempelajari perilaku perpindahan konsumen secara lebih komprehensif.

\section{Metode Penelitian}

Penelitian ini menggunakan metode literatur review terhadap beberapa artikel yang dipublikasikan dari tahun 2010 sampai dengan 2017. Artikel diambil dari publisher 
INOBIS: Jurnal Inovasi Bisnis dan Manajemen Indonesia

Volume 1, Nomor 1, Desember 2017

\section{Syaifuddin Fahmi}

emeraldinsight dan elsevier yang di akses oleh peneliti dengan menggunakan kata kunci "consumer switching behavior". Beberapa kriteria yang dijadikan landasan dalam pemilihan artikel antara lain :

1. Hanya artikel yang bertema "consumer switching behavior" yang diambil sebagai bahan review.

2. Artikel diterbitkan oleh publisher science direct dan emerald pada periode tahun 2010 sampai dengan 2017.

3. Artikel dalam bentuk conference paper (prosiding), tesis atau disertasi yang di publikasikan tidak dimusukkan dalam bahan kajian.

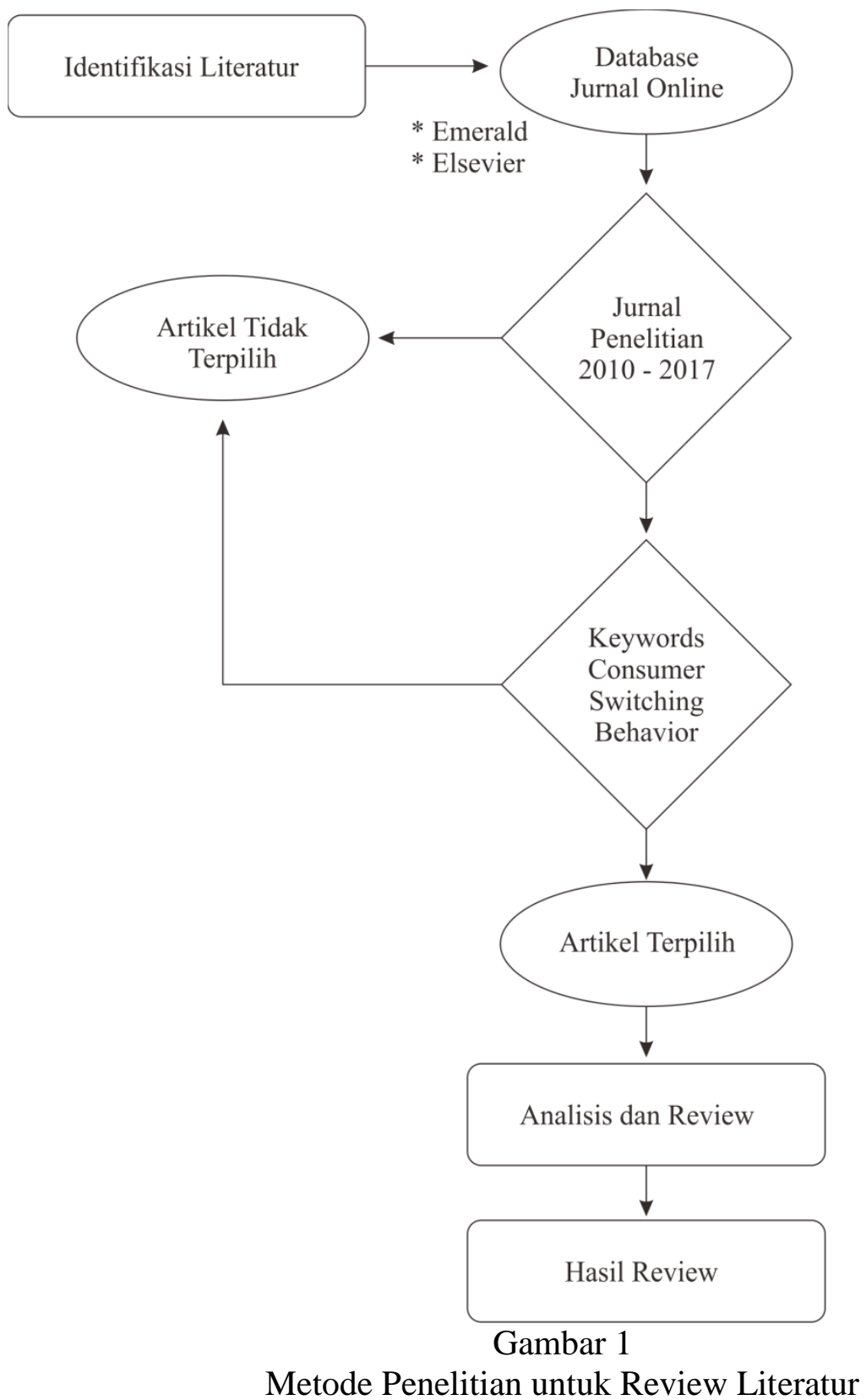

\section{Hasil dan Pembahasan}

Dari hasil pencarian literatur menggunakan kata kunci "consumer switching behavior" pada dua publisher jurnal yaitu emerald dan elsevier ditemukan 13 jurnal yang sesuai. Kriteria 
INOBIS: Jurnal Inovasi Bisnis dan Manajemen Indonesia

Volume 1, Nomor 1, Desember 2017

\section{Syaifuddin Fahmi}

dari masing masing jurnal berdasarkan judul dan penerbit bisa di lihat dari tabel 1. Hasil menunjukkan bahwa jumlah penelitian dengan tema perilaku perpindahan konsumen atau "consumer switching behavior" masih relatif sedikit dan membutuhkan banyak pengembangan melalui penelitian-penelitian baru.

Tabel 1

Distribusi Artikel berdasarkan Nama Jurnal dan Tahun Terbit

\begin{tabular}{|c|c|c|c|c|c|c|c|c|c|}
\hline \multirow{2}{*}{ No } & \multirow{2}{*}{ Nama Jurnal } & \multicolumn{8}{|c|}{ Tahun Dipublikasikan 2010 - 2017} \\
\hline & & $' 10$ & ' 11 & ' 12 & 6 & '14 & '15 & ' 16 & '17 \\
\hline 1 & $\begin{array}{l}\text { Computers in Human Behavior } \\
\text { Judul Artikel : } \\
\text { "Understanding users' switching } \\
\text { behavior of mobile instant } \\
\text { messaging applications: An } \\
\text { empirical study from the } \\
\text { perspective of push-pull- } \\
\text { mooring framework" }\end{array}$ & & & & & & & & 1 \\
\hline 2 & $\begin{array}{l}\text { Electronic Commerce Research and } \\
\text { Applications } \\
\text { Judul Artikel : } \\
\text { "Applying push-pull-mooring to } \\
\text { investigate channel switching } \\
\text { behaviors:M-shopping self-efficacy } \\
\text { and switching costs as moderators" }\end{array}$ & & & & & & & & 1 \\
\hline 3 & $\begin{array}{l}\text { Journal of Product \& Brand } \\
\text { Management } \\
\text { Judul Artikel : } \\
\text { "Building a comprehensive model } \\
\text { to investigate factors behind } \\
\text { switching intention of high- } \\
\text { technology products" }\end{array}$ & & & & & & & & 1 \\
\hline 4 & $\begin{array}{l}\text { Aslib Journal of Information } \\
\text { Management } \\
\text { Judul Artikel : } \\
\text { "Understanding users' switching } \\
\text { intentions and switching } \\
\text { behavior on social networking } \\
\text { sites" }\end{array}$ & & & & & & & & 1 \\
\hline 5 & Management Research Review & & & & & & & 1 & \\
\hline
\end{tabular}


INOBIS: Jurnal Inovasi Bisnis dan Manajemen Indonesia

Volume 1, Nomor 1, Desember 2017

Syaifuddin Fahmi

\begin{tabular}{|c|c|c|c|c|c|}
\hline & $\begin{array}{l}\text { Judul Artikel : } \\
\text { "Research on customer switching } \\
\text { behavior in the service industry" }\end{array}$ & & & & \\
\hline 6 & $\begin{array}{l}\text { Journal of Services Marketing } \\
\text { Judul Artikel : } \\
\text { "The market performance } \\
\text { indicator: a macro understanding } \\
\text { of service provider switching" }\end{array}$ & & & & 1 \\
\hline 7 & $\begin{array}{l}\text { Computers in Human Behavior } \\
\text { Judul Artikel : } \\
\text { "User-switching behavior in social } \\
\text { network sites: A model perspective } \\
\text { with drill-down analyses" }\end{array}$ & & & 1 & \\
\hline 8 & $\begin{array}{l}\text { International Journal of Bank } \\
\text { Marketing } \\
\text { Judul Artikel : } \\
\text { "Drivers of customers' switching } \\
\text { behaviour in Indian banking } \\
\text { industry" }\end{array}$ & & & 1 & \\
\hline 9 & $\begin{array}{l}\text { Journal of Product \& Brand } \\
\text { Management } \\
\text { Judul Artikel : } \\
\text { "Brand switching of high- } \\
\text { technology capital products: how } \\
\text { product features dictate the } \\
\text { switching decision" }\end{array}$ & & & 1 & \\
\hline 10 & $\begin{array}{l}\text { Journal of Services Marketing } \\
\text { Judul Artikel : } \\
\text { "Exploring switching behavior of } \\
\text { US mobile service customers" }\end{array}$ & & 1 & & \\
\hline 11 & $\begin{array}{l}\text { Journal of Retailing and Consumer } \\
\text { Services } \\
\text { Judul Artikel : } \\
\text { "Explaining Consumers' Channel- } \\
\text { Switching Behavior Using the } \\
\text { Theory of Planned Behavior } \\
(T P B) \text { " }\end{array}$ & 1 & & & \\
\hline
\end{tabular}


INOBIS: Jurnal Inovasi Bisnis dan Manajemen Indonesia

Volume 1, Nomor 1, Desember 2017

Syaifuddin Fahmi

\begin{tabular}{|l|l|l|l|l|l|l|l|l|l|}
\hline 12 & $\begin{array}{l}\text { Journal of Economic and } \\
\text { Administrative Sciences } \\
\text { Judul Artikel : } \\
\text { "Factors Affecting Switching } \\
\text { Behavior of Mobile Service Users: } \\
\text { The Case of Jordan" }\end{array}$ & 1 & & & & & & & \\
\hline 13 & $\begin{array}{l}\text { International Journal of Bank } \\
\text { Marketing } \\
\text { Judul Artikel : } \\
\text { "Customer switching behaviour in } \\
\text { the } \\
\text { Chinese retail banking industry" }\end{array}$ & 1 & & & & & & & \\
\hline \\
Jumlah jurnal berdasarkan tahun
\end{tabular}

Sumber : Data diolah, 2017

Tabel 2

Klasifikasi Artikel berdasarkan Temuan dan Hasil

\begin{tabular}{|c|c|c|}
\hline No. & $\begin{array}{c}\text { Penulis, Tahun } \\
\text { dan Judul Penelitian }\end{array}$ & Temuan dan Hasil \\
\hline 1 & $\begin{array}{l}\text { (Yongqiang Sun \& c, } \\
\text { 2017) } \\
\text { "Understanding users' } \\
\text { switching behavior of } \\
\text { mobile instant messaging } \\
\text { applications: An } \\
\text { empirical study from the } \\
\text { perspective of push-pull- } \\
\text { mooring framework" } \\
\text { *Elsevier Journal }\end{array}$ & $\begin{array}{l}\text { Variabel kelelahan atau kebosanan dengan layanan } \\
\text { Mobile Instant Messaging (MIM) dan norma subjektif } \\
\text { memiliki efek positif yang signifikan pada niat } \\
\text { melakukan switching, sedangkan inersia memiliki efek } \\
\text { negatif terhadap niat switching. Dilain sisi, komitmen } \\
\text { afektif, biaya switching dan kebiasaan ditemukan } \\
\text { signifikan terhadap inersia. Sedangkan variabel lain } \\
\text { seperti kekecewaan terhadap MIM dan daya tarik } \\
\text { produk baru tidak memberikan dampak yang cukup } \\
\text { signifikan terhadap perilaku switching. }\end{array}$ \\
\hline 2 & $\begin{array}{l}\text { (Hsin Hsin Chang, 2017) } \\
\text { "Applying push-pull- } \\
\text { mooring to investigate } \\
\text { channel switching } \\
\text { behaviors: } \\
\text { M-shopping self-efficacy } \\
\text { and switching costs as } \\
\text { moderators" } \\
\text { *Elsevier Journal }\end{array}$ & $\begin{array}{l}\text { Efek push and pull memiliki dampak langsung pada } \\
\text { niat beralih, dengan pengecualian biaya pencarian } \\
\text { yang harus dirasakan. Persepsi terhadap harga } \\
\text { memiliki pengaruh signifikan negatif terhadap persepsi } \\
\text { nilai, sedangkan persepsi nilai juga memiliki pengaruh } \\
\text { signifikan negatif terhadap niat berpindah. Efek tambat } \\
\text { (Mooring), termasuk m-shopping self-efficacy, biaya } \\
\text { saklar prosedural dan relasional, memiliki tingkat efek } \\
\text { moderat yang bervariasi terhadap perilaku pencarian } \\
\text { informasi, nilai yang dirasakan, daya tarik toko mobile } \\
\text { dan niat beralih atau (switching behavior). }\end{array}$ \\
\hline
\end{tabular}


INOBIS: Jurnal Inovasi Bisnis dan Manajemen Indonesia

Volume 1, Nomor 1, Desember 2017

Syaifuddin Fahmi

\begin{tabular}{|c|c|c|}
\hline 3 & $\begin{array}{l}\text { (Cristelle Msaed, 2017) } \\
\text { "Building a } \\
\text { comprehensive model to } \\
\text { investigate factors } \\
\text { behind } \\
\text { switching intention of } \\
\text { high-technology } \\
\text { products" } \\
\text { *Emerald Journal }\end{array}$ & $\begin{array}{l}\text { Perceived product usefulness, perceived ease of use } \\
\text { dan relative advantage dari fitur produk adalah faktor } \\
\text { utama yang mendorong niat pengguna untuk beralih, } \\
\text { sedangkan norma subjektif memiliki dampak yang } \\
\text { terbatas. Biaya keuangan untuk melakukan switching } \\
\text { merupakan hambatan utama bagi keputusan konsumen } \\
\text { untuk beralih ke teknologi baru. Sementara secara } \\
\text { afektif perasaan senang yg dimiliki konsumen terhadap } \\
\text { merek mereka dan merek lainnya terkait secara positif } \\
\text { dengan sikap mereka dalam perilaku switching. }\end{array}$ \\
\hline 4 & $\begin{array}{l}\text { (Chun-Nan Lin, 2017) } \\
\text { "Understanding users' } \\
\text { switching intentions and } \\
\text { switching } \\
\text { behavior on social } \\
\text { networking sites" } \\
\text { *Emerald Journal }\end{array}$ & $\begin{array}{l}\text { Variabel persepsi terhadap nilai, kualitas dan nilai } \\
\text { sosial memiliki pengaruh yang signifikan terhadap niat } \\
\text { untuk beralih. Variabel kepercayaan juga menjadi } \\
\text { salah satu yang mempengaruhi switching intention. Di } \\
\text { sisi lain persepsi terhadap resiko memiliki pengaruh } \\
\text { signifikan negatif terhadap niat berpindah. Sedangkan } \\
\text { variabel niat berpindah memiliki pengaruh signifikan } \\
\text { positif terhadap perilaku aktual dalam berpindah } \\
\text { switching. }\end{array}$ \\
\hline 5 & $\begin{array}{l}\text { (Yi-Fei Chuang \& } \\
\text { industry", 2016) } \\
\text { "Research on customer } \\
\text { switching behavior in the } \\
\text { service industry" } \\
\text { *Emerald Journal }\end{array}$ & $\begin{array}{l}\text { Theory of planned behavior (TPB) adalah salah satu } \\
\text { yang umum dipergunakan dalam meneliti perilaku } \\
\text { berpindah (switching behavior). Variabel Kepuasan, } \\
\text { biaya switching dan daya tarik layanan alternatif } \\
\text { adalah variabel prediktor yang paling umum } \\
\text { digunakan untuk menjelaskan maksud switching. } \\
\text { Biaya Beralih, norma subjektif dan hubungan } \\
\text { interpersonal memoderasi hubungan antara niat beralih } \\
\text { dan antesedennya. }\end{array}$ \\
\hline 6 & $\begin{array}{l}\text { (Steven, Lester, M., \& } \\
\text { Leanne, 2015) } \\
\text { "The market } \\
\text { performance indicator: a } \\
\text { macro understanding of } \\
\text { service provider } \\
\text { switching" } \\
\text { *Emerald Journal }\end{array}$ & $\begin{array}{l}\text { Varibel nilai dan kepuasan memiliki pengaruh yang } \\
\text { signifikan terhadan niat untuk beralih. Market } \\
\text { Performance Indicator (MPI) memiliki pengaruh } \\
\text { positif terhadap persepsi kepuasan dan nilai, dan } \\
\text { berkontribusi kuat terhadap perilaku switching secara } \\
\text { aktual. Hasil juga menunjukkan bahwa perbaikan pada } \\
\text { MPI menyebabkan hubungan antara perilaku aktual } \\
\text { dan aktual, yang menunjukkan bahwa mungkin ada } \\
\text { tingkat ambang yang penting, di mana perilaku } \\
\text { switching yang lebih besar terjadi. }\end{array}$ \\
\hline 7 & $\begin{array}{l}\text { (Yu-Lung Wua, 2014) } \\
\text { "User-switching } \\
\text { behavior in social } \\
\text { network sites: A model } \\
\text { perspective }\end{array}$ & $\begin{array}{l}\text { Model penelitian yang diusulkan sepenuhnya } \\
\text { didukung dengan verifikasi keempat hipotesis yang } \\
\text { diidentifikasi dalam penelitian empiris ini, di mana } \\
\text { kualitas layanan dan biaya switching secara tidak } \\
\text { langsung mempengaruhi niat untuk beralih. Variabel } \\
\text { Kepuasan dan penghalang perilaku beralih (switching }\end{array}$ \\
\hline
\end{tabular}


INOBIS: Jurnal Inovasi Bisnis dan Manajemen Indonesia

Volume 1, Nomor 1, Desember 2017

Syaifuddin Fahmi

\begin{tabular}{|c|c|c|}
\hline & $\begin{array}{l}\text { with drill-down } \\
\text { analyses" } \\
\text { *Elsevier Journal }\end{array}$ & $\begin{array}{l}\text { barrier) masing-masing menjadi mediasi dimana } \\
\text { (biaya switching yang lebih tinggi dan meningkatnya } \\
\text { level kepuasan memiliki peranan dalam menghambat } \\
\text { niat untuk beralih). }\end{array}$ \\
\hline 8 & $\begin{array}{l}\text { (Vishal Vyas, 2014) } \\
\text { "Drivers of customers' } \\
\text { switching behaviour in } \\
\text { Indian banking } \\
\text { industry" } \\
\text { *Emerald Journal }\end{array}$ & $\begin{array}{l}\text { Penggerak perilaku switching adalah hasil dari } \\
\text { pengalaman layanan negatif yang mungkin terkait } \\
\text { dengan faktor-faktor lain. Sembilan faktor yang } \\
\text { diidentifikasi sebagai konstruksi dasar dari banyak } \\
\text { variabel yang diukur yang dimaksudkan untuk } \\
\text { mengukur perilaku switching dan memerlukan } \\
\text { perhatian adalah: } \\
\text { 1) komitmen pelanggan terhadap bank } \\
\text { 2) Persepsi kualitas layanan } \\
\text { 3) Persaingan iklan yang efektif } \\
\text { 4) Produk layanan yang ditawarkan } \\
\text { 5) Kepuasan pelanggan } \\
\text { 6) Tanggapan terhadap kegagalan layanan } \\
\text { 7) Reputasi dan citra bank } \\
\text { 8) Harga, termasuk suku bunga yang dikenakan } \\
\text { atau dibayar. } \\
\text { 9) switching karena terpaksa. }\end{array}$ \\
\hline 9 & $\begin{array}{l}\text { (Sam Al-Kwifi, 2014) } \\
\text { "Brand switching of } \\
\text { high-technology capital } \\
\text { products: how product } \\
\text { features dictate the } \\
\text { switching decision" } \\
\text { *Emerald Journal }\end{array}$ & $\begin{array}{l}\text { Fitur produk merupakan faktor yang paling } \\
\text { berpengaruh yang mendasari peralihan merek. Selain } \\
\text { fitur produk faktor lain yang dapat mendasari } \\
\text { peralihan merek atau sebaliknya mencegah perilaku } \\
\text { beralih dan mampu mempertahankan keunggulan } \\
\text { kompetitif perusahaan adalah : Faktor pelayanan, } \\
\text { faktor harga, faktor hubungan dengan pengguna, dan } \\
\text { faktor dukungan teknologi atas produk. }\end{array}$ \\
\hline 10 & $\begin{array}{l}\text { (Arvind Malhotra, 2013) } \\
\text { "Exploring switching } \\
\text { behavior of US mobile } \\
\text { service customers" } \\
\text { *Emerald Journal }\end{array}$ & $\begin{array}{l}\text { Kualitas layanan mobile (M-Servqual) adalah faktor } \\
\text { penting untuk dapat mengalihkan niat pelanggan untuk } \\
\text { melakukan switching, jika pelanggan menganggap } \\
\text { penyedia layanan kurang inovatif, mereka cenderung } \\
\text { beralih ke penyedia lain. Persepsi akan inovasi sama } \\
\text { pentingnya dengan persepsi kualitas layanan yang } \\
\text { diberikan oleh provider dan persepsi inovasi } \\
\text { perusahaan secara positif mempengaruhi niat } \\
\text { konsumen untuk membeli lebih banyak layanan } \\
\text { tambahan tanpa harus berpindah layanan. }\end{array}$ \\
\hline 11 & $\begin{array}{l}\text { (Sanjukta Pookulangara, } \\
\text { 2011) } \\
\text { "Explaining Consumers' } \\
\text { Channel-Switching }\end{array}$ & $\begin{array}{l}\text { Sikap terhadap perpindahan saluran dipengaruhi secara } \\
\text { signifikan oleh kepercayaan hedonis dan utilitarian } \\
\text { terhadap toko dan katalog. Namun, dalam kasus } \\
\text { saluran internet, sikap terhadap saluran-switching } \\
\text { hanya dipengaruhi oleh kepercayaan utilitarian. }\end{array}$ \\
\hline
\end{tabular}


INOBIS: Jurnal Inovasi Bisnis dan Manajemen Indonesia

Volume 1, Nomor 1, Desember 2017

Syaifuddin Fahmi

\begin{tabular}{|c|c|c|}
\hline & $\begin{array}{l}\text { Behavior Using the } \\
\text { Theory of Planned } \\
\text { Behavior (TPB)" } \\
\text { *Elsevier Journal }\end{array}$ & $\begin{array}{l}\text { Keyakinan normatif secara negatif mempengaruhi } \\
\text { norma subjektif. Semua saluran Self-efficacy, } \\
\text { informasi, dan jenis produk merupakan faktor penting } \\
\text { yang mempengaruhi persepsi kontrol perilaku (PBC) } \\
\text { di semua saluran. Waktu hanya mempengaruhi PBC } \\
\text { dalam katalog, dan uang tidak mempengaruhi PBC di } \\
\text { salah satu saluran. Sikap dan norma subjektif } \\
\text { mempengaruhi perpindahan saluran niat untuk tiga } \\
\text { saluran, sedangkan PBC merupakan prediktor } \\
\text { signifikan untuk niat beralih saluran hanya untuk } \\
\text { katalog dan internet. }\end{array}$ \\
\hline 12 & $\begin{array}{l}\text { (Mohammad Suleiman } \\
\text { Awwad, 2010) } \\
\text { "Factors Affecting } \\
\text { Switching Behavior of } \\
\text { Mobile Service } \\
\text { Users: The Case of } \\
\text { Jordan" } \\
\text { *Emerald Journal }\end{array}$ & $\begin{array}{l}\text { Variabel harga (price), ketidaknyamanan } \\
\text { (inconvinience), kegagalan layanan (Core service } \\
\text { failure ) dan Ketanggapan karyawan terhadap } \\
\text { kegagalan layanan (responsiveness to service failures) } \\
\text { berpengaruh signifikan terhadap perilaku beralih } \\
\text { konsumen. Begitu pula variabel daya tarik oleh } \\
\text { pesaing, perubahan teknologi, dan biaya perpindahan } \\
\text { atau switching, berpengaruh signifikan pada perilaku } \\
\text { beralih pengguna layanan mobile. }\end{array}$ \\
\hline 13 & $\begin{array}{l}\text { (Michael D. Clemes, } \\
\text { 2010) } \\
\text { "Customer switching } \\
\text { behaviour in the } \\
\text { Chinese retail banking } \\
\text { industry" } \\
\text { *Emerald Journal }\end{array}$ & $\begin{array}{l}\text { Temuan penelitian mengungkapkan bahwa variabel } \\
\text { harga, reputasi, kualitas layanan, periklanan yang } \\
\text { efektif, penggantian paksa, jarak, dan biaya switching } \\
\text { berdampak pada perilaku switching nasabah bank. } \\
\text { Temuan ini juga mengungkapkan bahwa kelompok } \\
\text { muda dan kelompok berpenghasilan tinggi cenderung } \\
\text { beralih layanan bank. }\end{array}$ \\
\hline
\end{tabular}

Sumber : Data diolah, 2017

Dalam kaitanya dengan perilaku berpindah, Michael D. Clemes, dkk (2010), melakukan penelitian tentang keputusan konsumen untuk mengganti bank. Dari hasil survey yang dilakukan terhadap 421 nasabah bank di Jiaozuo City, Provinsi Henan, China, diperoleh peringkat faktor-faktor yang berdampak pada perilaku switching bank nasabah. Temuan penelitian mengungkapkan bahwa harga, reputasi, kualitas layanan, periklanan efektif, penggantian paksa, jarak, dan biaya switching berdampak pada perilaku switching nasabah bank. Temuan ini juga mengungkapkan bahwa kelompok berpenghasilan muda dan berpenghasilan tinggi cenderung beralih ke bank. Hasil penelitian ini memungkinkan pemasar layanan dan praktisi untuk mengembangkan dan menerapkan strategi pemasaran jasa untuk mengurangi tingkat pembelotan pelanggan, dan pada gilirannya, meningkatkan keuntungan bank.

Di lain sisi Sam Al-Kwifi, dkk (2014), mengungkapkan faktor-faktor yang mendukung brand switching dan pencitraan produk medis oleh pengguna pasar massal. Sebagian besar literatur tentang switching merek difokuskan pada produk pasar yang 
INOBIS: Jurnal Inovasi Bisnis dan Manajemen Indonesia

Volume 1, Nomor 1, Desember 2017

\section{Syaifuddin Fahmi}

kompetitif, dimana biaya switching dapat dikelola. Namun, sedikit pertimbangan diberikan pada merek switching produk modal berteknologi tinggi. Hasilnya mengkonfirmasi harapan bahwa fitur produk merupakan faktor yang paling berpengaruh yang mendasari peralihan merek. Fitur produk sangat penting bagi organisasi medis yang ingin mempertahankan keunggulan kompetitif mereka. Temuan menunjukkan bahwa serangkaian faktor yang mempengaruhi keputusan beralih adalah unik bagi pengguna dari segmen pasar yang berbeda di industri yang sama (misalnya pengguna utama dan pengguna pasar massal). Perbedaan ini berasal dari pemanfaatan teknologi masing-masing segmen pasar.

Faktor-faktor yang mempengaruhi niat berpindah (switching intention) pada pelanggan atau nasabah dunia perbankan diantaranya di pengaruhi oleh sikap konsumen terhadap produk atau sebuah layanan perbankan, Maya F. Farah, (2017). Studi yang dilakukan pada pemegang rekening di Spanyol menunjukkan adanya hubungan langsung yang signifikan antara niat beralih dan masing-masing: keyakinan perilaku, kepercayaan normatif, sikap, dan norma subjektif. Hasil juga mengungkapkan hubungan terbalik yang berarti antara niat beralih dan kedua keyakinan kontrol dan kontrol perilaku yang dirasakan. Osama Sam Al-Kwifi, dkk (2015), melakukan kajian dari sudut pandan berbeda tentang perkembangan historis dan pengembangan literatur tentang switching merek mengeksplorasi untuk menentukan pendahulunya yang menyebabkan perilaku switching di kalangan konsumen dan dampak beralihnya pangsa pasar perusahaan. Hasil penelitian menunjukkan bahwa merek muncul pada produk sejak lama dan berkembang melalui sejumlah tahap berdasarkan lingkungan ekonomi dan sosial. Literatur mengungkapkan bahwa tidak ada model tunggal yang dapat menjelaskan perilaku perpindahan merek atau switching. Konsumen atau bisnis di berbagai industri dan produk. Setiap penelitian menggunakan seperangkat faktor tertentu untuk menjelaskan peralihan merek. Namun, daya tarik merek bisa dihitung sebagai faktor yang paling umum dibalik brand switching.

Hsin Hsin Chang, dkk (2017), menggunakan model push-pull-mooring untuk menyelidiki niat switching channel konsumen yang berhubungan dengan toko fisik dan mobile. Efek push meliputi perilaku pencarian informasi mobile (dengan keuntungan dan biaya pencarian yang dirasakan sebagai anteseden) dan nilai yang dirasakan (dengan kualitas layanan yang dirasakan dan harga yang dirasakan sebagai anteseden) produk dan layanan yang diperoleh di toko fisik. Efek tarik adalah evaluasi konsumen akan daya tarik toko mobile (dengan karakteristik mobile dan persepsi kualitas mobile store sebagai anteseden). Selain itu, belanja mobile self-efficacy dan biaya switching dihipotesiskan sebagai efek tambat yang ikut campur dalam efek push and pull. Hasilnya menunjukkan bahwa efek push and pull memiliki dampak langsung pada niat beralih, dengan pengecualian biaya pencarian yang dirasakan. Efek tambat, termasuk m-shopping self-efficacy, biaya prosedural dan relasional, memiliki tingkat efek moderat yang bervariasi terhadap perilaku pencarian informasi, nilai yang dirasakan, daya tarik toko mobile dan niat beralih.

Penerapan teori migrasi push-pull-mooring (PPM) dalam mengukur alasan perpindahan juga dipergunakan oleh Jishim Jung, dkk (2017), yaitu menguji penerapan PPM untuk pemilihan maskapai penerbangan untuk memperjelas perilaku switching mereka. Berdasarkan tinjauan literatur dan survei terbuka yang ekstensif, diperoleh identifikasi empat faktor dorongan, tiga daya tarik, dan empat faktor tambat. Survei lapangan dilakukan di sebuah bandara internasional di Korea Selatan, Hasil menunjukkan bahwa model PPM yang terdiri dari struktur faktor sekunder memberi representasi yang dapat diterima dari variabel yang diamati dalam perbandingan dengan model konstruksi orde pertama. Hasil analisis struktural juga menunjukkan bahwa semua kategori PPM secara langsung mempengaruhi niat switching. Selain itu, dimensi tambat memiliki pengaruh moderat terhadap hubungan antara 
INOBIS: Jurnal Inovasi Bisnis dan Manajemen Indonesia

Volume 1, Nomor 1, Desember 2017

\section{Syaifuddin Fahmi}

kategori pull dan switching intention. Namun, tidak ada efek moderat faktor tambat pada hubungan antara faktor pendorong dan niat switching yang ditemukan.

Mengenai dua prediktor lain dari niat beralih, hadir dalam penelitian ini - yaitu, biaya switching yang dirasakan dan daya tarik alternatif yang dirasakan - biaya switching yang dirasakan nampaknya lebih signifikan karena efek beralih niat baik secara langsung maupun tidak langsung melalui kepuasan pelanggan. Hal ini sesuai dengan temuan dari penelitian sebelumnya (Aydin et al., 2005; Burnham et al., 2003; Chebat dkk., 2011; Jones et al., 2000; Lam, dkk., 2004; Lee dkk., 2001; Pilih dan Eisend, 2013; Wathne et al., 2001). Perceived alternative attractiveness, di Tangan lain, ditemukan sebagai prediktor lemah untuk mengalihkan niat karena hanya efek moderat melalui kepuasan pelanggan yang diamati, yang kontras dengan penelitian sebelumnya yang menunjukkan efek langsung dari daya tarik alternatif yang dirasakan pada niat beralih (Bansal \& Taylor, 2002), (Bansal et al., 2005; Burnham et al., 2003; Jones, et al., 2000; Pick and Eisend, 2013). Satu penjelasan mengapa daya tarik alternatif yang dirasakan memiliki efek langsung yang tidak signifikan terhadap niat beralih pada MTM Bangladesh mungkin karena variabel lain, seperti biaya switching yang dirasakan, kepuasan pelanggan, dan lain-lain, memiliki pengaruh yang lebih besar terhadap niat beralih dan pelanggan tidak menemukan penyedia layanan lainnya.

Michael D. Clemes, (2010), mengungkapkan bahwa, keputusan untuk mengganti layanan dihipotesiskan menjadi fungsi harga, reputasi, kualitas layanan, persaingan iklan yang efektif, switching tidak disengaja, jarak, biaya switching, jarak, dan karakteristik demografis. Temuan penelitian mengungkapkan bahwa harga, reputasi, kualitas layanan, periklanan efektif, penggantian paksa, jarak, dan biaya switching berdampak pada perilaku switching. Temuan ini juga mengungkapkan bahwa kelompok berpenghasilan muda dan berpenghasilan tinggi cenderung beralih ke bank. Vishal Vyas, dkk (2014) juga memiliki pendapat yang tidak jauh berbeda. Perang harga dan persaingan ketat di industri perbankan India telah menyebabkan bank menjadi salah satu ancaman utama untuk beralih. Konsumen sekarang lebih banyak harga dan layanan sadar dalam perilaku pembelian jasa keuangan mereka. Mereka lebih cenderung mengubah perilaku perbankan mereka karena produk dan layanan perbankan hampir identik. Tujuan makalah ini adalah untuk memberikan wawasan tentang driver yang mengarahkan pelanggan berpindah dari satu penyedia layanan ke layanan lain. Hasil menunjukkan bahwa harga, reputasi, tanggapan terhadap kegagalan layanan, kepuasan pelanggan, kualitas layanan, produk layanan, persaingan, komitmen pelanggan dan penggantian paksa berpengaruh signifikan terhadap perilaku switching pelanggan.

\section{Kesimpulan}

Dari hasil review literatur diketahui bahwa, dalam perspektif pembentuk perilaku berpindah (switching behavior) terdapat beberapa sudut pandang berbeda dari para peneliti sebelumnya, sebagian beranggapan bahwa niat untuk berperilaku dibentuk oleh perubahan sikap dan peranan dari faktor-faktor pembentuk perilaku seperti norma subjektif (subjective norm), keyakinan normatif (Normative Beliefs) dan keyakinan berperilaku (Behaviors Beliefs), sebagaimana dapat kita temui dalam Theory of Reasoned Action (TRA), (Fishbein \& Ajzen, 1980). Beberapa peneliti menambahkan persepsi terhadap kontrol perilaku menjadi variabel pembentuk niat, sebagaimana terdapat dalam Theory of Planned Behavior (TPB), (Ajzen, 2005). Dalam beberapa hasil penelitian ditemukan bahwa sudut pandang kemanfaatan penggunaan teknologi memiliki peranan penting terhadap pembentukkan sikap dan perilaku konsumen, yaitu dengan masuknya persepsi atas kegunaan atau kemanfaatan (percieved of usefulness) serta persepsi atas kemudahan (percieved ease of use) dalam teori Technology Acceptance Model (TAM). 
INOBIS: Jurnal Inovasi Bisnis dan Manajemen Indonesia

Volume 1, Nomor 1, Desember 2017

\section{Syaifuddin Fahmi}

Penelitian terbaru menunjukkan bahwa teori Push and Pull Mooring (PPM) dirasakan lebih tepat dipergunakan untuk mengukur dan menganalisis perilaku perpindahan layanan "switching behavior". Yaitu dengan memasukkan faktor pendorong (push factors), faktor penarik (pull factors) dan faktor yang menjadi penghambat perpindahan (mooring factors). Teori PPM menghasilkan sudut pandang yang lebih luas dalam melihat faktor yang melatarbelakangi konsumen untuk berpindah, yaitu tidak hanya dari sudut pandang produk yang saat ini di dipergunakan namun juga memasukkan daya tarik produk lain dan peranan beberapa faktor penghambat dalam melakukan perpindahan.

\section{Daftar pustaka}

Ajzen, I. (2005). Attitudes, Personality and Behavior (2nd ed.). Berkshire, UK: Open University Press-McGraw Hill Education.

Amelie Gamble, E. A. J., Tommy Gärling. (2009). Consumer attitudes towards switching supplier in three deregulated markets. The Journal of Socio-Economics, 38, 814-819. doi: 10.1016/j.socec.2009.05.002

Arvind Malhotra, C. K. M. (2013). Exploring switching behavior of US mobile service customers. Journal of Services Marketing, 27(1), 13-24. doi: $10.1108 / 08876041311296347$

Bansal, H. S., \& Taylor, S. F. (2002). Investigating Interactive Effects in the Theory of Planned Behavior in a Service-Provider Switching Context. Psychology \& marketing, 19(5), 407-426.

Chun-Nan Lin, H.-Y. W. (2017). Understanding users' switching intentions and switching behavior on social networking sites. Aslib Journal of Information Management, 69(2), 201-214. doi: 10.1108/AJIM-08-2016-0127

Cristelle Msaed, S. O. A.-K., Zafar U. Ahmed. (2017). Building a comprehensive model to investigate factors behind switching intention of high-technology products. Journal of Product \& Brand Management, 26(2), 102-119. doi: 10.1108/JPBM-06-2015-0915

Fishbein, M., \& Ajzen, I. (1980). Understanding attitudes and predicting social behavior (Vol. 1st). USA: Prentice Hall, Inc.

Hsin Hsin Chang, K. H. W., Shi Yu Li. (2017). Applying push-pull-mooring to investigate channel switching behaviors: M-shopping self-efficacy and switching costs as moderators. Electronic Commerce Research and Applications, 24, 50-67. doi: http://dx.doi.org/10.1016/j.elerap.2017.06.002

http://www.tempo.co. (2017). PT. Gojek Indonesia.

https://www.kominfo.go.id. (2014). jumlah pengguna smartphone dan media internet di Indonesia. Retrieved 2017, 2014, from https://www.kominfo.go.id

Internetworldstats.com. (2016). The number of internet users and penetration in indonesia. from http://www.internetworldstats.com/asia.htm

Jishim Jung, H. H., Mihae Oh. (2017). Travelers' switching behavior in the airline industry from the perspective of the push-pull-mooring framework. Tourism Management, 59, 139-153. doi: 10.1016/j.tourman.2016.07.018

Keaveney, M. S. (1995). Customer Switching Behavior In Service Industries: An Exploratory Study. Journal of marketing, 59(2).

Keaveney, S. M. d. P., M. . (2001). Customer Switching Behavior in Online Services: An Exploratory Study of the Role of Selected Attitudinal, Behavioral, and Demographic Factors. Journal of the Academy of Marketing Science, 29(4), 374-390. 
INOBIS: Jurnal Inovasi Bisnis dan Manajemen Indonesia

Volume 1, Nomor 1, Desember 2017

Syaifuddin Fahmi

Michael D. Clemes, C. G., Dongmei Zhang. (2010). Customer switching behaviour in the Chinese retail banking industry. International Journal of Bank Marketing, 28(7), 519546. doi: https://doi.org/10.1108/02652321011085185

Mohammad Suleiman Awwad, B. A. N. (2010). Factors Affecting Switching Behavior of Mobile Service Users: The Case of Jordan. Journal of Economic and Administrative Sciences, 26(1), 27-51. doi: 10.1108/10264116201000002

Philip Gerrard, J. B. C. (2004). Consumer switching behavior in the Asian banking market. Journal of Services Marketing, 18(3), 215-223. doi: https://doi.org/10.1108/08876040410536512

Sam Al-Kwifi, Z. U. A., Dina Yammout. (2014). Brand switching of high-technology capital products: how product features dictate the switching decision. Journal of Product \& Brand Management, 23(4/5), 322-332. doi: http://dx.doi.org/10.1108/JPBM-12-2013$\underline{0473}$

Sanjukta Pookulangara, J. H., Ge Xiao. (2011). Explaining consumers'channel-switching behavior using the theory of planned behavior. Journal of Retailing and Consumer Services, 18, 311-321. doi: 10.1016/j.jretconser.2011.02.005

Steven, D. A., Lester, J., M., G. D., \& Leanne, C. (2015). The market performance indicator: a macro understanding of service provider switching. Journal of Services Marketing, 29(4), 302-313. doi: doi:10.1108/JSM-05-2014-0172

Vishal Vyas, S. R. (2014). Drivers of customers' switching behaviour in Indian banking industry. International Journal of Bank Marketing, 32(4), 321-342. doi: https://doi.org/10.1108/IJBM-04-2013-0033

Yi-Fei Chuang, Y.-F. T., (2016) "Research on customer switching behavior in the service, \& industry", M. R. R., Vol. 39 Issue: 8, pp.925-939. (2016). Research on customer switching behavior in the service industry. Management Research Review, 39(8), 925939. doi: 10.1108/MRR-01-2015-0022

Yongqiang Sun, D. L., Sijing Chen, Xingrong Wu, Xiao-Liang Shen,, \& c, X. Z. (2017). Understanding users' switching behavior of mobile instant messaging applications: An empirical study from the perspective of push-pullmooring framework. Computers in Human Behavior, 75, 727-738. doi: 10.1016/j.chb.2017.06.014

Yu-Lung Wua, Y.-H. T., Ching-Pu Li, Sheng-Yuan Wang, Chi-Yuan Chiu. (2014). Userswitching behavior in social network sites: A model perspective with drill-down analyses. Computers in Human Behavior, 33, 92-103. doi: 10.1016/j.chb.2013.12.030

Zeeshan Ahmed, M. G., Usman Rafiq. (2015). Factors Affecting Consumer Switching Behavior: Mobile Phone Market in Manchester- United Kingdom. International Journal of Scientific and Research Publications, 5, 1-7. 